\title{
ANNOUNCEMENTS
}

\section{THE INTERNATIONAL CODE OF ZOOLOGICAL NOMENCLATURE}

The following Opinions (listed by number) have been published recently by the International Commission on Zoological Nomenclature (see Bulletin Zoological Nomenclature, 35, part 2, 31 October 1978).

Opinion No.

1108 (p. 94) Conservation of Marstonia Baker, 1926 and of Amnicola lustrica Pilsbry, 1890 (Mollusca, Gastropoda).

1109 (p. 97) Cerithium Bruguière [1789] (Gastropoda): designation of type-species under plenary powers.

1113 (p. 106) Alpheus neptunus Dana, 1852 (Crustacea, Alpheidae): status of a neotype confirmed.

1114 (p. 108) Cornuspira Schultze, 1854 (Foraminifera): conserved under the plenary powers.

THE NAPLES ZOOLOGICAL STATION

The Naples Zoological Station has arrangements with the Royal Society for British marine biologists to work there for periods of a few weeks on topics of their own choice, making use of the facilities available there for international use. Typical subjects of research by U.K. scientists in recent years have been studies of the nervous system of cephalopods, the use of bacteria as pollution indicators, algal symbiosis in molluscs and the biochemistry of feeding mechanisms in lower marine invertebrates. Applications for table-time may be made through the Royal Society, the Physiological Society or one of the ten contributing U.K. universities (details from the Executive Secretary of the Royal Society). The Royal Society will also consider applications for financial support through its European Science Exchange Programme or from its Browne Fund for marine research. 